\title{
Biochemical and ultrastructural alterations in the brain of mice induced by aqueous leaf extract of a medicinal plant, Lantana camara L. and its amelioration by nimodipine and flunarizine
}

\author{
H. Ashalata Singha ${ }^{1}$, Mahuya Sengupta $^{2}$, Meenakshi Bawari ${ }^{1 *}$ \\ ${ }^{1}$ Department of Life Science and Bioinformatics, Assam University, Silchar, Assam, India. \\ ${ }^{2}$ Department of Biotechnology, Assam University, Silchar, Assam, India.
}

\section{ARTICLE INFO}

Article history:

Received on: July 30, 2020

Accepted on: February 02, 2021

Available online: May 10, 2021

\section{Key words:}

Acetylcholinesterase,

brain,

Lantana camara L.,

medicinal plant,

Oxidative stress,

Ultrastructure.

\section{ABSTRACT}

Lantana camara L., a plant used as an ethnomedicine, is considered to be toxic. In this context, evaluation of neurotoxic effect of $L$. camara was studied. Here, experimental mice were orally administered with an aqueous leaf extract of $L$. camara (AQLC) $(500 \mathrm{mg} / \mathrm{kg}$ body weight) for 14 days. Biochemical assays, acetylcholinesterase (AChE) activity as well as microscopic studies were performed to assess its neurotoxic effects. Administration (per oral) of AQLC in mice induced significant oxidative damage in the brain cortex and cerebellum as evidenced by increased lipid peroxidation, protein carbonylation, and also the activity of AChE. This was associated with declining of the endogenous antioxidants such as superoxide dismutase and glutathione peroxidase. Co-treatment of calcium channel blockers, nimodipine ( $20 \mathrm{mg} / \mathrm{kg}$ body weight) and flunarizine $(10 \mathrm{mg} / \mathrm{kg}$ body weight $)$ along with the aqueous extract of $L$. camara were seemed to ameliorate the neurotoxic effect caused by AQLC. Furthermore, disintegration in the ultrastructure of brain cortex induced by L. camara was restored by treating calcium channel blockers. Altogether, the findings of this study concluded that the AQLC has potential neurotoxic effect in mice.

\section{INTRODUCTION}

Lantana camara L. belonging to the Family - Verbenaceae is a well-known traditional medicine used by indigenous people all over the world. It is commonly known as wild sage or Lantana. Despite its medicinal properties, L. camara is also considered as a noxious weed and is reported to be toxic [1,2]. The presence of two triterpenic acids, lantadene $\mathrm{A}$ and lantadene $\mathrm{B}$ in $L$. camara induces intra hepatic cholestasis [3-6]. It has been reported that ingesting foliage of $L$. camara by cattle caused hepatotoxicity [7]. It is also reported that the phytochemical studies of different species of Lantana showed the presence of alkaloids, steroids and terpenoids. Kazmi et al., 2012 reported that a terpenoid compound, ursolic acid stearoyl glucoside possess anticonvulsant. and depressant like effect [8]. Terpenoids affect the intracellular calcium ions and facilitated the inhibition of calcium ion $\left(\mathrm{Ca}^{2+}\right)$ influx through L-type $\mathrm{Ca}^{2+}$ channels $[9,10]$.

Oxidative stress is caused due to the disturbance between the reactive oxygen species (ROS) and reactive nitrogen species which leads to oxidative cellular damage. Brain is sensitive to oxidative damage

\footnotetext{
*Corresponding Author

Meenakshi Bawari,

Department of Biotechnology, Assam University, Silchar, Assam, India

E-mail:mbawari.aus@gmail.com
}

thereby interfering with the normal function of neuron leading to cell death [11]. Free radicals produced by oxidative damage cause disintegration of plasma membrane and due to which ionic gradients get disbalanced eventually leading to excess ions in the cell which includes calcium. Calcium ion is an important second messenger in the central nervous system (CNS) and its signaling pathway takes part in the survival and functional of neurons. Accumulation of calcium intracellularly is thought to be the main factor of cellular death [12].

Regulation of calcium homeostasis can be regulated by voltagegated calcium channels which are categorized into groups such as high-voltage activated calcium channels (L-type) and low-voltage activated calcium channels (T-type). Both L-type and T-type calcium channels are found in CNS and have been developed to treat various neurological diseases [13-15]. Nimodipine (NIM), an L-type calcium channel blocker inhibits the calcium influx through voltage sensitive L-type calcium channels and promotes the cerebral flow. It is lipophilic in nature enabling it to cross the blood brain barrier and enter the brain. It has been reported that it improves the neurologic recovery after global ischemia, reducing damage caused by brain edema [16]. On one hand, flunarizine (FLU) blocks T-type calcium channels. In the previous studies, it has been shown to attenuate the neurotoxic effects of iron and display anticonvulsant effect in maximum electroshockinduced seizure mice [17]. 
In the present study, we aim to determine the neurotoxic effects of aqueous extract of L. camara $(500 \mathrm{mg})$ in mice by performing biochemical assays, AchE activity as well as examining ultrastructure by transmission electron microscope (TEM). The study also evaluates the amelioration of the effects of two calcium channel blockers, NIM and FLU in mice.

\section{METHODOLOGY}

\subsection{Drugs and Chemicals}

Ketamine hydrochloride, thiobarbituric acid (TBA), trichloroacetic acid (TCA), 5,5'-dithios-bis-2-nitrobenzoic acid (DTNB), and dinitrophenyl-hydrazine (DNPH) were obtained from Sigma Aldrich, India. NIM, flunarizine, pyrogallol, glutathione reductase, and hydrogen peroxide were obtained from Hi-media Ltd., India. All other reagents and chemicals were of highest analytical grades (SRL, Merck: India).

\subsection{Plant Samples}

Fresh leaves of L. camara were collected from Cachar district, Assam, India in its respective season. The plant was subjected to identification and authentication at the Botanical Survey of India, Shillong, Meghalaya, India bearing number BSI/ERC/2015/Plant Identification/669 and voucher specimen bearing number Ph.D./AUS/ ASLC/19 to the Department of Life Science and Bioinformatics, Assam University, Silchar.

\subsection{Extraction of Plant}

The plants collected were dried under the shade and ground to powder form. Thirty grams of leaf parts of the plant were cold percolated with $300 \mathrm{ml}$ of distilled water for $72 \mathrm{~h}$. The obtained extract was made to concentrate and evaporated at $50^{\circ} \mathrm{C}$ to get crude extract. The dried extract was stored in air tight container at $4^{\circ} \mathrm{C}$ for further use [18].

\subsection{Animals}

Experiments were conducted using thirty adult Swiss albino mice weighing ( $8-9$ weeks; $25 \pm 5 \mathrm{~g} ; n=5$ ). The animals were housed in a hygienic condition and were maintained at appropriate temperature. The mice received a standard diet and water ad libitum and were acclimatized for at least a week before the beginning of experiment. The care and use of experimental animals were processed according to the Assam University Animal Ethics Committee (Regn. No. -AUS/ IAEC/2017/PC/07).

\subsection{Acute Toxicity and Experimental Design}

The median lethal dose of L. camara was established according to OECD 423 guideline. Mice were fasted for $16 \mathrm{~h}$ and randomly divided into six groups with four mice per group. The first group is the control receiving saline water and the rest groups were graded doses of the plant extracts treated orally, that is, $800 \mathrm{mg} / \mathrm{kg}, 1200 \mathrm{mg} / \mathrm{kg}, 1600 \mathrm{mg} / \mathrm{kg}$, $2000 \mathrm{mg} / \mathrm{kg}$, and $3000 \mathrm{mg} / \mathrm{kg}$. The acute lethal dose was calculated using SPSS version 19.0 for probit analysis [19,20]. As a result, LD 50 of the extract of $L$. camara was found to be $2480 \mathrm{mg} / \mathrm{kg}$ body weight. The dose for the present study was selected one-fifteenth of the lethal dose. Mice were observed for behavioral changes and mortality for a period of $48 \mathrm{~h}$. Animals were then divided into six groups of seven animals each. In each group, five animals were used for biochemical assays of whole brain tissue and two animals for ultrastructural study. Group 1 is the untreated control group; Group 2 received aqueous crude extract of L. camara (500 mg/kg body weight); Group 3 received NIM with a dose of $20 \mathrm{mg} / \mathrm{kg}$ body weight [21]; Group 4 received $10 \mathrm{mg} / \mathrm{kg}$ body weight dose of FLU [17]; Group 5 received a combination dose of $L$. camara $(500 \mathrm{mg} / \mathrm{kg})$ and NIM $(20 \mathrm{mg} / \mathrm{kg})$; and Group 6 received a dose of $500 \mathrm{mg} / \mathrm{kg} \mathrm{L}$. camara in parallel with FLU $(10 \mathrm{mg} / \mathrm{kg})$. All the groups were intragastrically treated for a period of 14 days.

\subsection{Preparation of Brain Tissues}

At the end of exposure day, animals were induced anesthesia by injecting a mixture of ketamine hydrochloride $(15 \mathrm{mg} / \mathrm{kg})$ and xylazine $(10 \mathrm{mg} / \mathrm{ml})$. Animals were sacrificed by cervical decapitation and the brain was immediately taken out, placed in chilled isotonic saline. Cerebrum and cerebellum were dissected out and minced into pieces and homogenized in a potassium phosphate buffer $(50 \mathrm{mM}, \mathrm{pH} 7.4)$. They are then divided into three portions: The first was centrifuged at $\times 700 \mathrm{~g}$ for $20 \mathrm{~min}$ for the estimation of lipid peroxidation (LPO) and protein carbonyl content (PC); the second portion was centrifuged at $\times 8500 \mathrm{~g}$ for $30 \mathrm{~min}$ to determine the activity of antioxidant parameters such as catalase (CAT), superoxide dismutase (SOD), and glutathione peroxidase (GPx); and the remaining portion was for the determination of acetylcholinesterase (AChE) activity and protein concentrations.

\subsection{Biochemical Parameters}

\subsubsection{Assay of malondialdehyde (MDA) levels (EC 1.11. 1.7)}

The levels of LPO in cerebrum and cerebellum were measured by Ohkawa et al. [22] by measuring MDA formation. Here, about $100 \mu 1$ of the tissue homogenate, $2 \mathrm{ml}$ of TCA, and $2 \mathrm{ml}$ of TBA reagent were added and mixed. It was then incubated in boiling water bath for 15 min, let it cooled and then centrifuged at $35000 \mathrm{rpm}$ for $10 \mathrm{~min}$ at room temperature. In this process, TBA reacts with LPO and results in the pink colored product, MDA and was estimated at $535 \mathrm{~nm}$. The lipid concentration was expressed in terms of nanomoles of MDA per $\mathrm{mg}$ of protein.

\subsubsection{Assay of superoxide dismutase, SOD (EC 1.15.1.1) activity} The SOD activity was assessed by the method of Marklund and Marklund [23] with slight modifications. Along with tissue homogenate, the mixture contained $0.2 \mathrm{mM}$ of pyrogallol, $1 \mathrm{mM}$ of EDTA, and $50 \mathrm{mM}$ of Tris-HCl buffer, $\mathrm{pH} 8.2$ were added. The SOD activity was performed by following the auto-oxidation of pyrogallol at $420 \mathrm{~nm}$ for $3 \mathrm{~min}$ and optical density was noted. One unit of SOD was defined as the $50 \%$ inhibition in pyrogallol auto oxidation $/ \mathrm{mg}$ protein/min.

\subsubsection{Assay of catalase, CAT (EC 1.11.1.6) activity}

Brain CAT activity was assayed by the method of Aebi [24]. Here, the decomposition rate of $\mathrm{H}_{2} \mathrm{O}_{2}$ was measured at $240 \mathrm{~nm}$. Briefly, $50 \mathrm{mM}$ phosphate buffer ( $\mathrm{pH} 7.0), 10 \mathrm{mM} \mathrm{H}_{2} \mathrm{O}_{2}$ and homogenates of cerebrum and cerebellum were allowed to react and the rate of $\mathrm{H}_{2} \mathrm{O}_{2}$ was noted for $30 \mathrm{~s}$. Results are represented as change in absorbance $/ \mathrm{min} / \mathrm{mg}$ protein.

\subsubsection{Assay of glutathione peroxidise, GPx (EC 1.11.1.9) activity}

The activity of GPx was assessed by the method of Rotruck et al. [25]. Briefly, the reaction mixture contained $0.2 \mathrm{ml}$ each of EDTA, sodium azide, $0.2 \mathrm{ml}$ of $4 \mathrm{mM}$ reduced glutathione, $\mathrm{H}_{2} \mathrm{O}_{2} ; 0.4 \mathrm{ml}$ of phosphate buffer, $0.1 \mathrm{ml}$ of homogenate and it was then incubated at $37^{\circ} \mathrm{C}$ for $10 \mathrm{~min}$. The reaction was arrested by the addition of $0.5 \mathrm{ml}$ of $10 \%$ TCA, and tubes were subjected to centrifugation at $2400 \mathrm{rpm} 10 \mathrm{~min}$. The supernatant $(0.2 \mathrm{ml})$ was then added with $4 \mathrm{ml}$ disodium hydrogen phosphate and $0.5 \mathrm{ml}$ of DTNB. The developed color was recorded at 
$420 \mathrm{~nm}$. The GPx activity was expressed in terms of $\mu \mathrm{g}$ of glutathione utilized $/ \mathrm{min} / \mathrm{mg}$ protein.

\subsubsection{Acetylcholinesterase, AChE (EC 3.1.1.7) activity}

The activity of AChE was assessed according to the procedure of Ellman et al. [26] in the cerebrum and cerebellum using acetylthiocholine iodide as substrate. Here, $10 \%$ brain (cerebrum and cerebellum) homogenates $(\mathrm{w} / \mathrm{v})$ were added to the test tubes containing $3 \mathrm{ml}$ of phosphate buffer, $0.02 \mathrm{ml}$ of acetylthiocholine solution and $0.1 \mathrm{ml}$ of DTNB. Acetylthiocholine was hydrolyzed by AChE to acetic acid and thiocholine. The catalytic activity was measured by following the increase of yellow anion, 5-thio-2-nitrobenzoate, produced from thiocholine when it reacted with DTNB at $412 \mathrm{~nm}$ and the results are expressed as $\mathrm{nmol} / \mathrm{min} / \mathrm{mg}$ protein.

\subsubsection{Protein carbonyl, $P C$}

The PC content of the cerebrum and cerebellum of mice brain was determined by the procedure as described by Levine et al. [27] using DNPH as a substrate. About $200 \mu 1$ of supernatant was added to 800 $\mu 1$ of $10 \mathrm{mM}$ DNPH in $\mathrm{HCl}$ and incubated for $1 \mathrm{~h}$ in the dark room at room temperature. One milliliter of $20 \%$ TCA was then added for precipitation for $5 \mathrm{~min}$ and then centrifuged at $\times 10,000 \mathrm{~g}$ for $10 \mathrm{~min}$. The pellets formed were washed off 3 times with 1:1 ethanol:ethyl acetate to remove excess DNPH. The pellets were then redissolved in $500 \mu \mathrm{l}$ of SDS solution. The amount of carbonyl compounds were measured at $370 \mathrm{~nm}$ and calculated using a molar extinction coefficient (E) of 22,000/M/cm after subtracting blank absorbance. The carbonyl content was expressed in $\mathrm{nmol} / \mathrm{mg}$ protein.

\subsubsection{Estimation of protein content}

Protein content of tissue homogenates was assayed by Folin-Phenol reaction as described by Lowry et al. [28] using bovine serum albumin as a standard.

\subsection{TEM Study}

Mice were anesthetized with a mixture of ketamine hydrochloride $(15 \mathrm{mg} / \mathrm{kg})$ and xylazine $(10 \mathrm{mg} / \mathrm{ml})$ and perfused transcardially with physiological saline and then fixed with a fixative solution containing $2 \%$ paraformaldehyde and $2.5 \%$ glutaraldehyde in $0.1 \mathrm{M}$ phosphate buffer [29].

\subsection{Statistical Analysis}

All statistical analyses were performed using SPSS version 19.0 software. Data were analyzed by one-way analysis of variance (ANOVA) followed by Tukey's HSD post hoc test with Bonferroni correction for multiple comparisons. The data were expressed as mean \pm SEM from five animals per treatment. The level of significance was set at $P<0.05$. All biochemical assays were repeated at least 4 times.

\section{RESULTS}

\subsection{Acute Toxicity}

The median lethal dose of the aqueous extract of $L$. camara L. was found out to be $2480 \mathrm{mg} / \mathrm{kg}$ body weight. The dose selected for this study was below the median lethal dose, that is, $500 \mathrm{mg} / \mathrm{kg}$.

\subsection{Effects of L. camara on Antioxidants in Cerebrum and Cerebellum}

Antioxidant enzymes are the first cellular molecules required for defense against ROS generation. The first enzyme of the enzymatic antioxidative pathway is SOD which converts superoxide anions into peroxides and then to water by CAT and GPx. Thus, in the present work, increased oxidative stress was evident by significant decreased GPx $(P<0.001)$ [Figure 1] and SOD $(P<0.001)$ [Figure 2] levels in cerebrum and cerebellum as compared to those of controls. Furthermore, there is a significant alteration in CAT level $(P<0.001)$, [Figure 3] in comparison to control groups. These make the agreement with the fact that $L$. camara reduced the total antioxidant levels enhancing imbalance between pro-oxidant and antioxidant potentials. These changes were significantly attenuated when co-treated with NIM and FLU.

\subsection{Effect of $L$. camara Induced Mice on LPO Activity}

In Figure 4, it demonstrated that the level of MDA in the cerebrum and cerebellum of the L. camara $(500 \mathrm{mg} / \mathrm{kg})$ induced mice was significantly elevated $(P<0.001)$ than that of the control group. This raise of LPO indicates an increase oxidative stress in the brain of L. camara treated mice. Interestingly, calcium antagonists NIM and FLU could attenuate the elevation.

\subsection{Effect of $L$. camara Treatment on AchE Activity}

The administration of $L$. camara in mice produced a significant decrease in the activity of AchE, an enzyme involve in the metabolism of acetylcholine in cerebrum $(P<0.001)$ and cerebellum $(P<0.05)$ as compared to control mice [Figure 5]. Simultaneously when NIM and FLU were treated singly, significant decrease of AchE activity was seen in comparison to control. However, the combined treatment of L. camara with NIM and FLU clearly improved the alteration in AchE activity when compared to L. camara treated group.

\subsection{Effect of $L$. camara Treatment on PC Content}

Administration of $L$ camara significantly increased protein oxidation in both cerebrum $(P<0.001)$ and cerebellum $(P<0.01)$ in comparison to the control [Figure 6]. The increase in $\mathrm{PC}$ was more pronounced in cerebrum than in cerebellum. Mice co-administered with NIM $(P<0.01)$ and FLU $(P<0.01 . P<0.05)$ showed significant decrease among the treated group.

\subsection{TEM Morphological Changes in the Cerebrum}

In Figure 7, aqueous extract of L. camara $(500 \mathrm{mg} / \mathrm{kg})$ administration was found to cause neuronal damage such as dense and clumpy chromatin; swollen mitochondria with disappeared cristae. Ruptured of axonal myelin sheath was also observed when compared with control. These changes were found to be reduced when treated combined with NIM $(20 \mathrm{mg} / \mathrm{kg})$.

\section{DISCUSSION}

In this study, we demonstrated that the administration of $500 \mathrm{mg} / \mathrm{kg}$ (orally) L. camara for 14 consecutive days was able to induce neurotoxicity in mice. The results from the study indicate that the aqueous extract of L. camara causes disturbances in cholinergic neurotransmission characterized by increased levels of acetylcholine associated with depletion of endogenous antioxidants (SOD, GPx) levels and increased levels of CAT and LPO in both cerebral cortex and cerebellum whereas co-administration of calcium channel blockers, NIM, and FLU with L. camara revealed a significantly better effect. So far, there is no study regarding the neurotoxic effect of $L$. camara in vivo on mice models. As a result, no reference could be provided to compare our results with the previous works. Studies have shown that CNS consumes $20 \%$ of the total body oxygen; hence, it is much more 

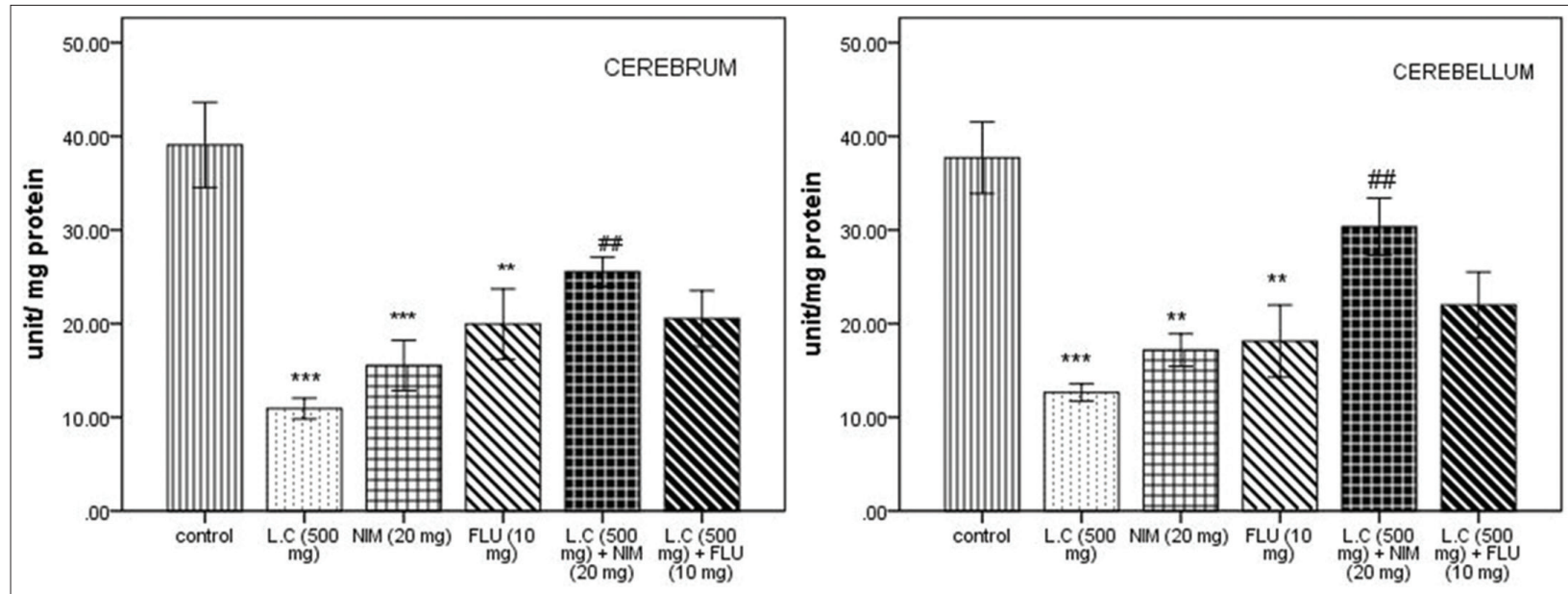

Figure 1: Effect of Lantana camara $(500 \mathrm{mg} / \mathrm{kg})$ along with nimodipine $(20 \mathrm{mg} / \mathrm{kg})$ and flunarizine $(20 \mathrm{mg} / \mathrm{kg})$ on GPx activity (U/mg protein) in cerebrum and cerebellum after 14 days of exposure. Values are given as mean \pm SEM of five mice per group. $* P<0.05, * * P<0.01, * * * P<0.001$ as compared with control group; $\# \mathrm{p}<0.05$ as compared with L. camara $(500 \mathrm{mg} / \mathrm{kg})$ group.
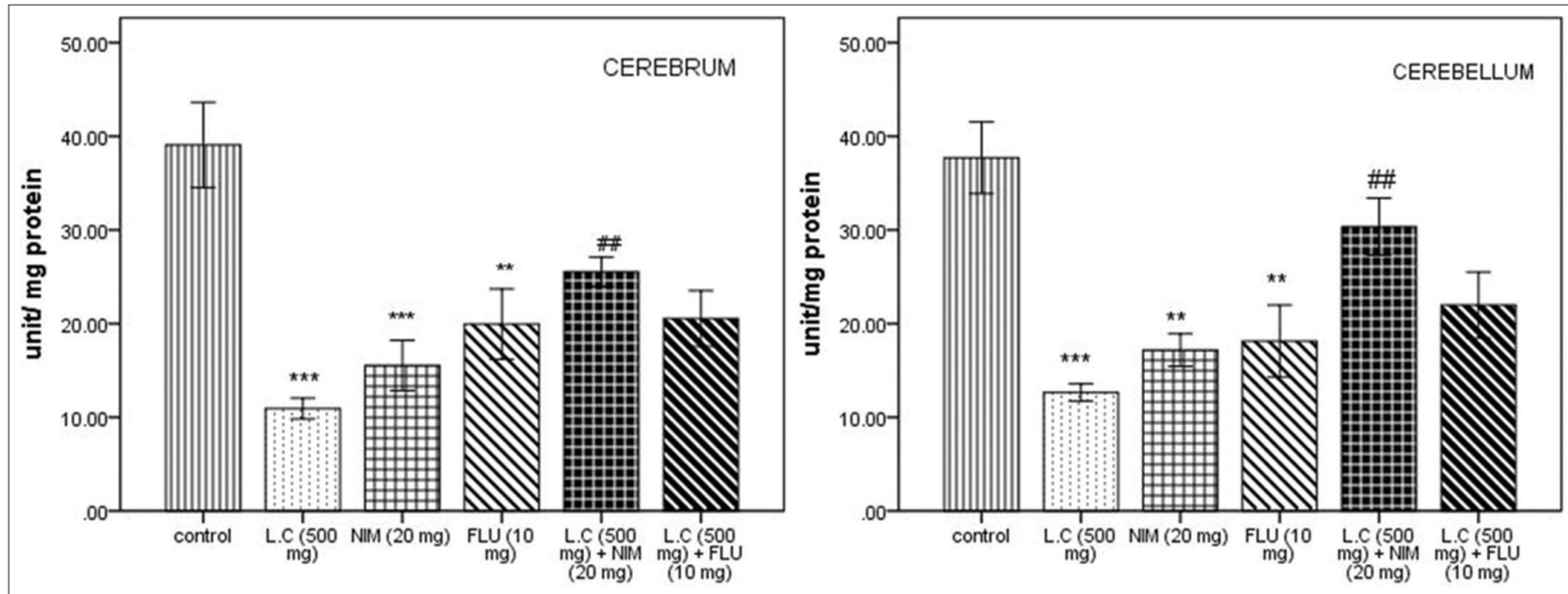

Figure 2: Effect of Lantana camara (500 mg/kg) along with nimodipine (20 mg/kg) and flunarizine (10 mg/kg) on SOD activity (U/mg protein) in cerebrum and cerebellum after 14 days of exposure. Values are given as mean \pm SEM of five mice per group. $* * P<0.01, * * * P<0.001$ when compared with control group; $\# \#<0.01$ as compared with L. camara $(500 \mathrm{mg} / \mathrm{kg})$ group.
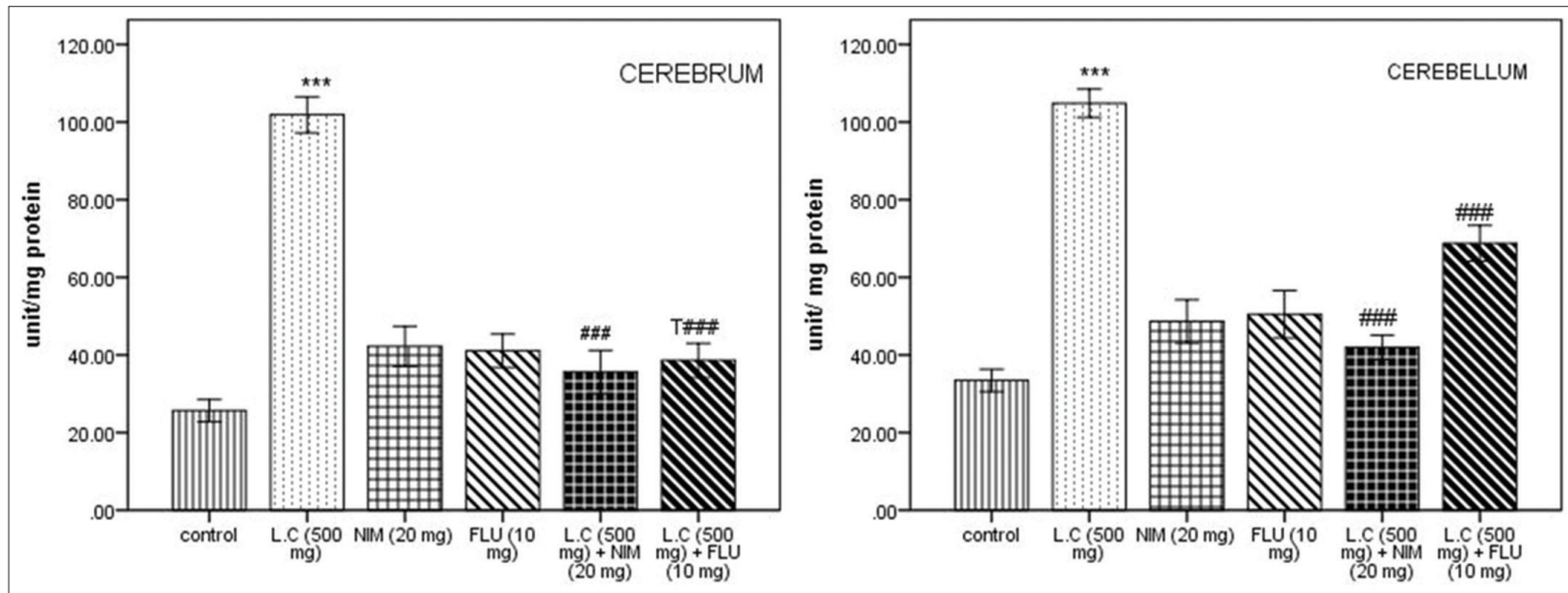

Figure 3: Effect of Lantana camara $(500 \mathrm{mg} / \mathrm{kg})$ along with nimodipine $(20 \mathrm{mg} / \mathrm{kg})$ and flunarizine $(10 \mathrm{mg} / \mathrm{kg})$ on catalase level $\left(\mathrm{nmol} \mathrm{H}_{2} \mathrm{O}_{2} / \mathrm{mg} \mathrm{protein}\right)$ in cerebrum and cerebellum after 14 days of exposure. Values are given as mean \pm SEM of five mice per group. $* * * P 0.001$ when compared with control group; $\# \# P<0.001$ as compared with L. camara $(500 \mathrm{mg} / \mathrm{kg})$ group. 

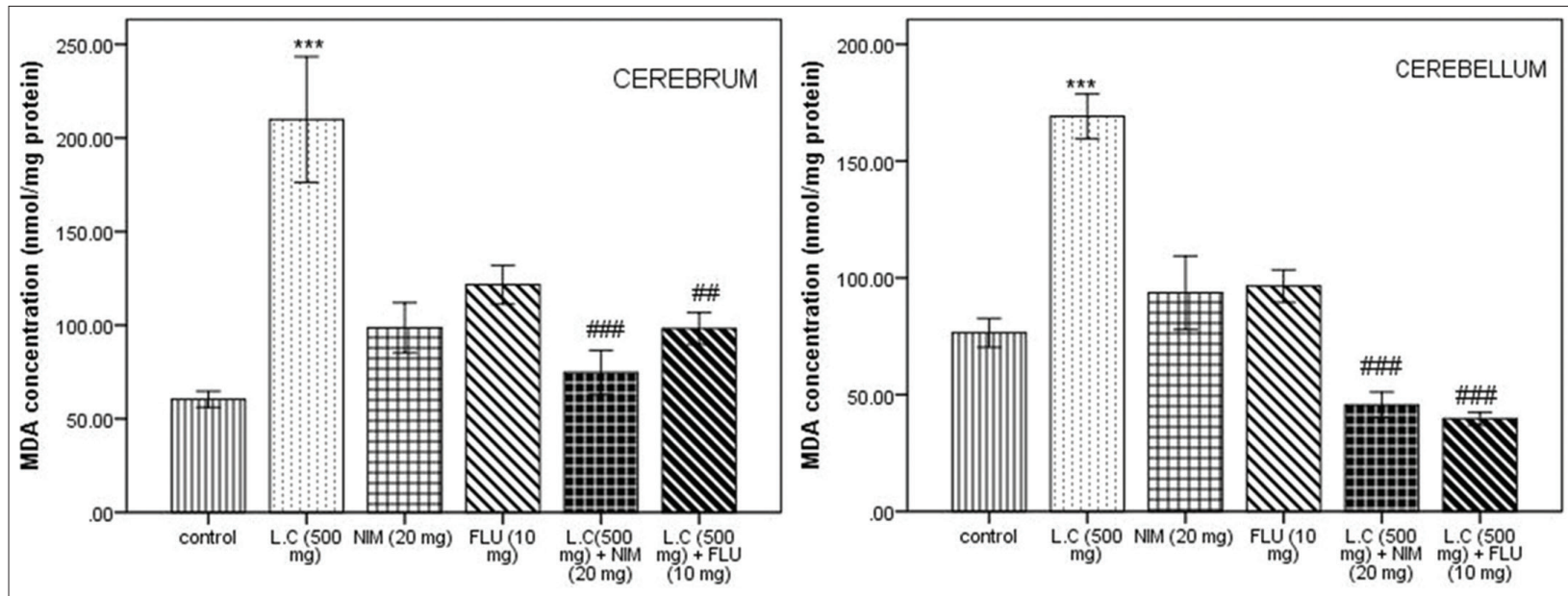

Figure 4: Effect of Lantana camara $(500 \mathrm{mg} / \mathrm{kg})$ along with nimodipine $(20 \mathrm{mg} / \mathrm{kg})$ and flunarizine $(10 \mathrm{mg} / \mathrm{kg})$ on malondialdehyde concentration (nmol/mg protein) in cerebrum and cerebellum after 14 days of exposure. Values are given as mean \pm SEM of five mice per group. ${ }^{* * *} P<0.001$ when compared with control group; \#\#P<0.01; \#\#\#<0.001 as compared with L. camara $(500 \mathrm{mg} / \mathrm{kg})$ group.
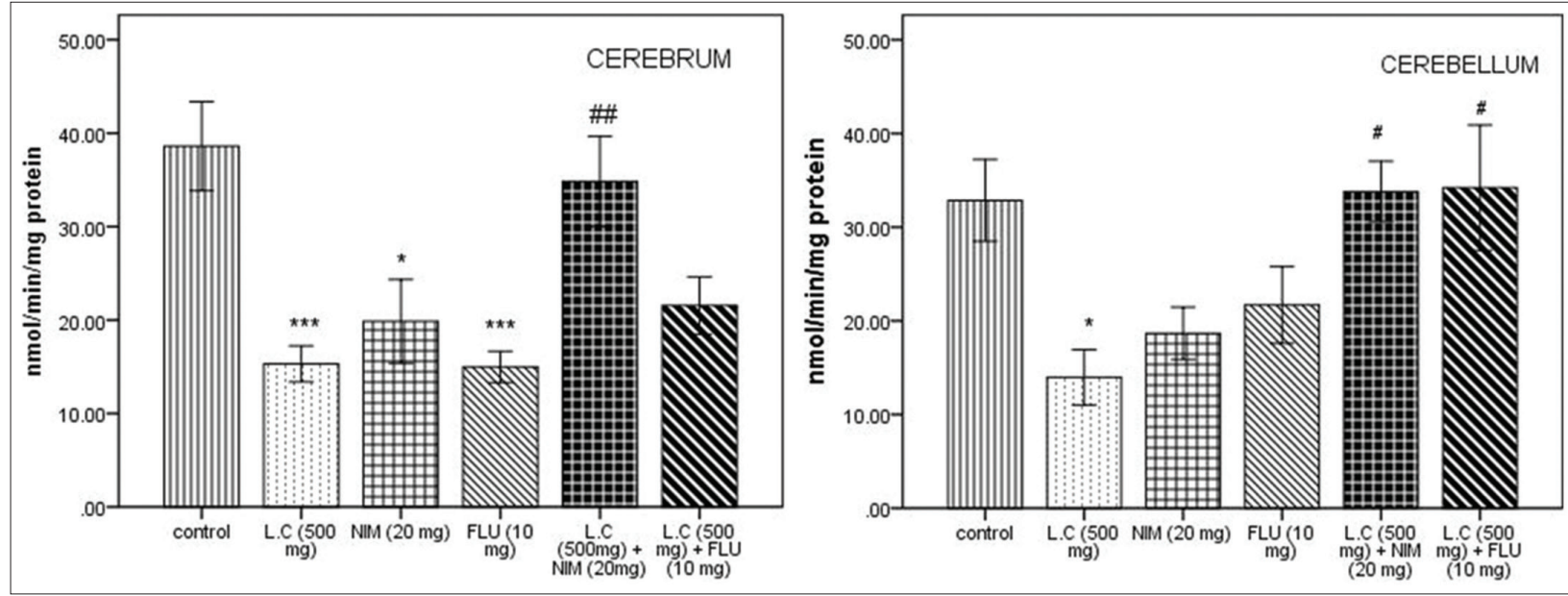

Figure 5: Effect of Lantana camara $(500 \mathrm{mg} / \mathrm{kg})$ along with nimodipine $(20 \mathrm{mg} / \mathrm{kg})$ and flunarizine $(10 \mathrm{mg} / \mathrm{kg})$ on acetylcholinesterase activity (nmol/ min/mg protein) in cerebrum and cerebellum after 14 days of exposure. Values are given as mean \pm SEM of five mice per group. $* P<0.05, * * * P<0.001$ when compared with control group; $\# P<0.05, \# \#<0.01$ as compared with $L$. camara $(500 \mathrm{mg} / \mathrm{kg})$ group.

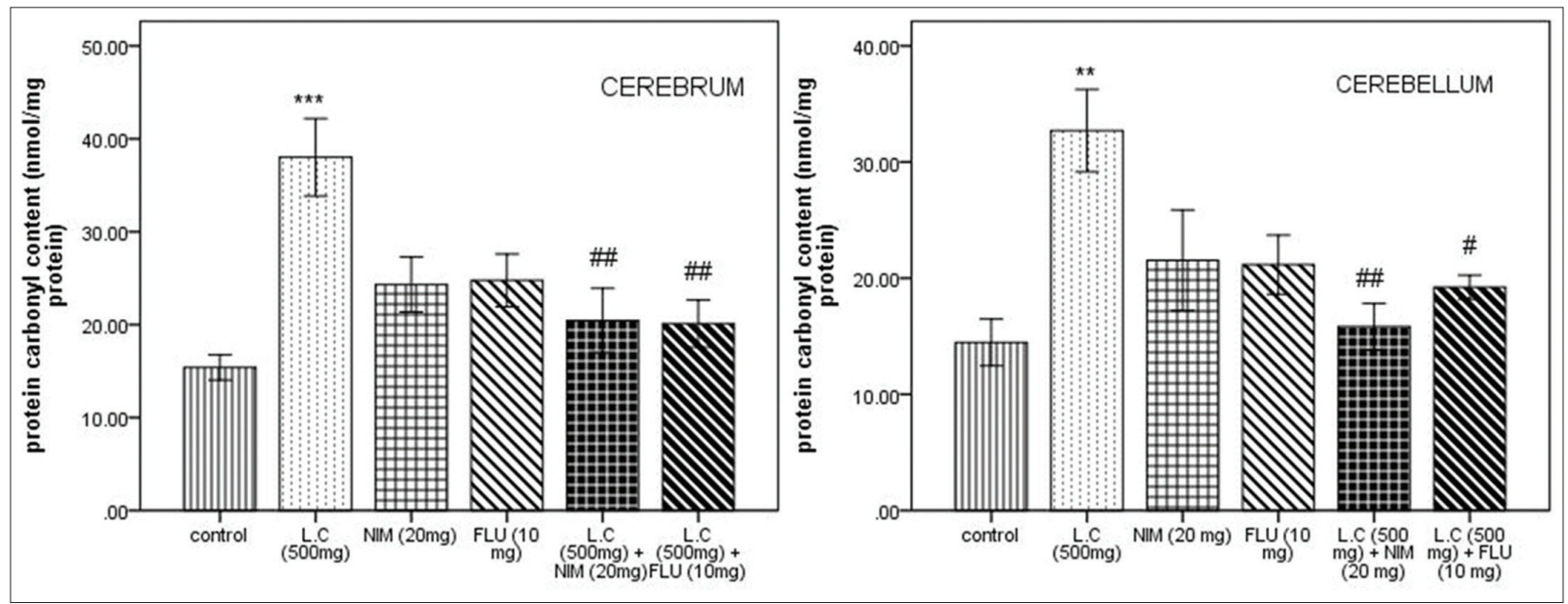

Figure 6: Effect of Lantana camara $(500 \mathrm{mg} / \mathrm{kg})$ along with nimodipine $(20 \mathrm{mg} / \mathrm{kg})$ and flunarizine $(10 \mathrm{mg} / \mathrm{kg})$ on protein carbonyl content (nmol/mg protein) in cerebrum and cerebellum after 14 days of exposure. Values are given as mean \pm SEM of five mice per group. $* * P<0.01, * * * P<0.001$ when compared with control group; $\# P<0.05, \# P<0.01$ as compared with L. camara $(500 \mathrm{mg} / \mathrm{kg})$ group. 


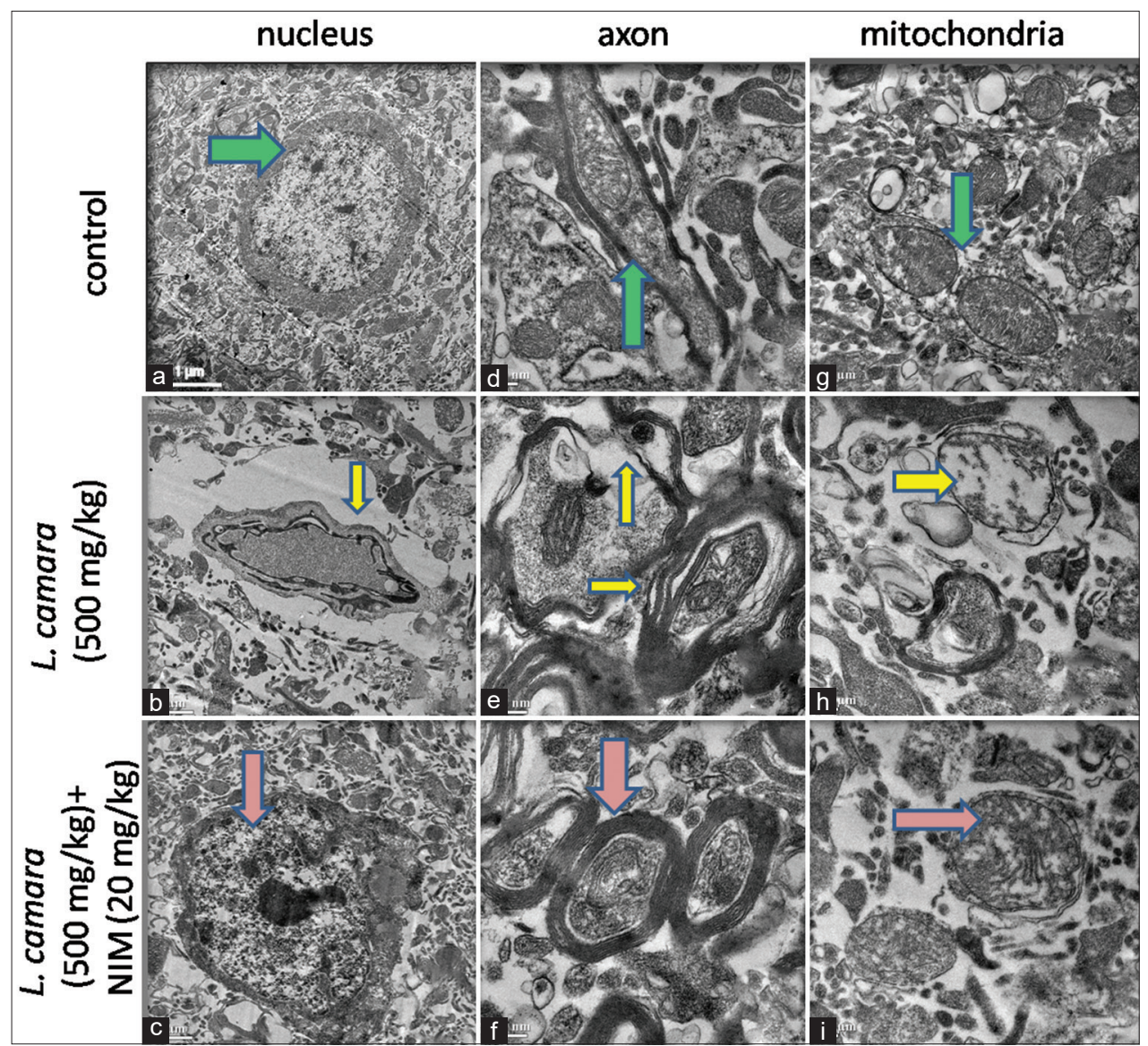

Figure 7: Effects of Lantana camara $(500 \mathrm{mg} / \mathrm{kg}$ ) on ultrastructural changes in cerebrum. Control group showing a normal nucleus, well distributed chromatin material and double layered nuclear membrane (a), normal axon with thick and tightly wrapped myelin sheath (d), double membrane mitochondria with wellorganized cristae can be noticed (g); L. camara treated group showing a distorted nucleus with disrupted nuclear membrane and dense chromatin material (b), detachment of myelin sheath from the axon (e), swollen and deformed mitochondrial membrane along with broken cristae was observed (h); (c) is the combined treatment of LC + nimodipine showing the reformation of nucleus maintaining the chromatin material intact and nuclear membrane, reconstruction of the myelin sheath was seen (f), in the image (i) reappearance of cristae can be seen. Scale bar- $\{\mathrm{A}, \mathrm{B}, \mathrm{C}: 1 \mu \mathrm{m}\} ;\{\mathrm{D}, \mathrm{E}, \mathrm{F}: 200 \mu \mathrm{m}\} ;$ and $\{\mathrm{G}, \mathrm{H}, \mathrm{I}: 0.2 \mu \mathrm{m}\}$.

vulnerable to oxidative damage caused by free radicals [11]. Calcium channel blockers, NIM, and FLU when treated alone has shown some adverse effects which indicated that they are not beneficial without oxidative stress.

High lipid content causes damaged to the brain leading to the activation of dihydropyridine-sensitive calcium currents and increases intracellular calcium levels in neurons [30]. It is seen that there was a significant increased MDA levels, an indicator of LPO, in both cerebrum and cerebellum when treated with the crude aqueous extract of $L$. camara as compared to control group which signs the efficiency of $L$. camara in releasing lipid products.

SOD is the enzyme which catalyzes dismutation of superoxide radical and also use as a substrate. Generation of SOD produces hydroxyl group as well as hydrogen peroxide, which induce LPO of cell membrane and the later got neutralized by the enzymes CAT and GPx. In our case, we noticed decreased SOD levels in cerebrum and cerebellum of $L$. camara treated mice compared to those found in controls. Antioxidant enzymes play the role of defense mechanism against ROS generation. Therefore, in the current work, rise in oxidative stress was evident by the depletion of GPx activity, elevation of CAT level in the cerebrum and cerebellum.
Proteins in the brain tissue are prone to ROS which has been hypothesized by several studies showing that PC groups got elevated by oxidative stress, eventually leads to upregulation of toxic byproducts in brain [31,32]. In the present study, we have found that the effect of $L$. camara on PC significantly increased as compared to control indicating the presence of oxidative stress and later attenuates by pre-treatment of calcium channel blockers, NIM, and FLU. Similar results are seen in the studies performed by Domijan et al., [33] Łukaszewicz-Hussain [34] which confirm that oxidative stress is the cause for the protein damage.

$\mathrm{AChE}$ is a protease that hydrolyses the neurotransmitter, acetylcholine and takes important part in conducting nerve action potential at the neuromuscular junctions and motor function. Alterations in the level of Ach or AchE activity may affect the cholinergic transmission process and leads to learning deficits. A significant increase in the Ach level in mice following $L$. camara treatment has been observed in the present study. Tair et al. [35] reported the same disturbances of AChE in brain when treated with aluminum.

There is a continuous production of free radicals in the process of oxidation and reduction reactions in the cell. When these free radicals exceed their threshold level, they begin to bind the unsaturated bonds 
of fatty acids and cholesterol leading to membrane peroxidation. This further disbalances the ionic concentrations and cations, especially calcium ions [36]. Rise in intracellular calcium levels in the brain mediates oxidative neuronal death. Oxidative stress induction also affects the calcium concentration in mitochondria [37,38].

Earlier studies conducted have shown that L. camara Linn. possess toxic compounds, Lantadene A and Lantadene B [39]. The possible mechanism to the toxic properties of the compounds is that the former compound triggers the gene BCL $2 \mathrm{~L} 1$ which regulate the cell death by binding to the anion channel and control the caspase activator, CYC1 found in the mitochondrial membrane. Furthermore, it promotes apoptosis when interacts with clusterin protein, CLU which releases and activates apoptosis regulator BAX [40]. The later targets the gene, NOS2 which produces nitric oxide mediating tumor and synthesizing pro-inflammatory cytokines such as IL6 and IL8 [41]. The toxic principle of the alcoholic crude extract of $L$. camara shown the depressive properties on CNS and has anxiolytic activity $[42,43]$.

It is reported that calcium channel blockers serve as membrane protecting agents by inhibiting the peroxidation of the lipid bilayer. Both $\mathrm{L}$ and $\mathrm{T}$ type of calcium channel blockers can protect by inhibiting calcium influx [44]. In the present study, both NIM and FLU were administered orally where NIM and FLU being treated before L. camara induction resulting in attenuation of excitotoxic damage in mice by preventing intracellular increase of calcium ions which induced anxiety. Furthermore, it was observed that combination of NIM with $L$. camara was significantly more effective than FLU in ameliorating oxidative damage in neurons.

The examination of TEM images of the brain tissue further confirmed that L. camara caused abnormal ultrastructural changes in the cerebrum including neuroapoptosis; mitochondrial changes such as loss of cristae, swollen, and elongated mitochondria as well as nuclear alterations; coarse and clumpy chromatin, non-myelination of axons. These changes were similar to the findings of $[45,46]$.

\section{CONCLUSION}

The potentiality of neurotoxic effect of $L$. camara may be considered. The present data show L. camara elevates the LPO level, protein oxidation, and AchE activity which eventually decrease the antioxidant levels. These markers are further proved by the disorientation of ultrastructural images caused by L. camara. Amelioration of induced neurotoxic is done by the pre-administration of the calcium channel blockers, NIM, and FLU. Furthermore, the protective effect was found to be L. camara concurrent with NIM. Taking into account the above findings, it can be concluded that the plant, L. camara Linn., is neurotoxic to mice at the given dose and hence, serious concern should be taken for the utilization of the plant when used as medicinal purpose.

\section{ACKNOWLEDGMENT}

We express our sincere thanks to the Director, Botanical Survey of India, Shillong, Meghalaya, for identification of the plant $L$. camara L.; SAIF (NEHU), Shillong, Meghalaya, India, for allowing us to perform TEM.

\section{AUTHORS' CONTRIBUTIONS}

Singha, HA. contributed to design and drafted manuscript; Sengupta, M. and Bawari, M. critically revised manuscript. All authors gave final approval and agree to be accountable for all aspects of work ensuring integrity and accuracy.

\section{DECLARATION OF CONFLICTING INTERESTS}

The author(s) declared no potential conflicts of interest with respect to the research, authorship, and/or publication of this article.

\section{FUNDING}

The author(s) disclosed receipt of the financial support for the research: This study was supported by University Grant Commission (UGC) providing NON-NET fellowship.

\section{PUBLISHER'S NOTE}

This journal remains neutral with regard to jurisdictional claims in published institutional affiliation.

\section{REFERENCES}

1. Garcia AF, Medeiros HC, Maioli MA, Lima MC, Rocha BA, da Costa FB, et al. Comparative effects of lantadene A and its reduced metabolite on mitochondrial bioenergetics. Toxicon 2010;55:1331-7.

2. Parimoo HA, Sharma R, Patil RD, Sharma OP. Hepatoprotective effect of Ginkgo biloba leaf extract on lantadenes-induced hepatotoxicity in Guinea pigs. Toxicon 2014;81:1-12.

3. Ali-Emmanuel N, Moudachirou M, Akakpo JA, Quetin-Leclercq J. Treatment of bovine dermatophilosis with Senna alata, Lantana camara and Mitracarpus scaber leaf extracts. J Ethnopharmacol 2003;86:167-71.

4. Singh A, Sharma OP, Bhat TK, Vats SK, Ojha S. Fungal degradation of lantadene A, the pentacyclic triterpenoid hepatotoxin of lantana plant. Int Biodeterior Biodegradation 2001;47:239-42.

5. Zoubiri S, Baaliouamer A. GC and GC/MS analyses of the Algerian Lantana camara leaf essential oil: Effect against Sitophilus granarius adults. J Saudi Chem Soc 2012;16:291-7.

6. Sharma S, Sharma OP, Singh B, Bhat TK. Biotransformation of lantadenes, the pentacyclic triterpenoid hepatotoxins of Lantana plant, in Guinea pig. Toxicon 2000;38:1191-202.

7. Sharma OP, Sharma S, Pattabhi V, Mahato SB, Sharma PD. A review of the hepatotoxic plant Lantana camara. Crit Rev Toxicol 2007;37:313-52.

8. Kazmi I, Gupta G, Afzal M, Anwar F. Anticonvulsant and depressantlike activity of ursolic acid stearoyl glucoside isolated from Lantana camara L. (verbanaceae). Asian Pacific J Trop Dis 2012:S453-6.

9. da Conceicao AO, de Oliveira FF, de Oliveira RA, Junior AS, Takser L, Reyes-Moreno C, et al. Lantana macrophylla Schauer (Verbenaceae) ethanolic extract induces activation of ERK1/2 and p38 MAPKs pathway and $\mathrm{Ca}^{2+}$ imbalance in human trophoblasts derived cell lines. Food Chem Toxicol 2012;50:1001-12.

10. Mbaveng AT, Hamm R, Kuete V. 19 harmful and protective effects of terpenoids from African medicinal plants. Toxicol Surv Afr Med Plants 2014;2014:557-76.

11. Drechsel DA, Patel M. Role of reactive oxygen species in the neurotoxicity of environmental agents implicated in Parkinson's disease. Free Radic Biol Med 2008;44:1873-86.

12. Lu J, Zheng Y, Wu D, Luo L, Sun D, Shan Q. Ursolic acid ameliorates cognition deficits and attenuates oxidative damage in the brain of senescent mice induced by D-galactose. Biochem Pharmacol 2007;74:1078-90.

13. Zapater P, Moreno J, Horga JF. Neuroprotection by the novel calcium antagonist PCA50938, nimodipine and flunarizine, in gerbil global brain ischemia. Brain Res 1997;772:57-62. 
14. Jain R, Bankey N, Jain A. Anticonvulsive effects of nifedipine and flunarizine on maximal electroshock seizures induced seizures. Natl J Physiol Pharm Pharmacol 2018;8:1317-20.

15. Bork K, Wurm F, Haller H, Strauss C, Scheller C, Gnanapragassam VS, et al. Neuroprotective and neuroregenerative effects of nimodipine in a model system of neuronal differentiation and neurite outgrowth. Molecules 2015;20:1003-13.

16. Yanpallewar SU, Hota D, Rai S, Kumar M, Acharya SB. Nimodipine attenuates biochemical, behavioral and histopathological alterations induced by acute transient and long-term bilateral common carotid occlusion in rats. Pharmacol Res 2004;49:143-50.

17. Bostanci MO, Bagirici F, Canan S. A calcium channel blocker flunarizine attenuates the neurotoxic effects of iron. Cell Biol Toxicol 2006;22:119-25.

18. Akindele AJ, Adeyemi OO. Analgesic activity of the aqueous leaf extract of Byrsocarpus coccineus. Niger J Heal Biomed Sci 2006;5:43-6.

19. Costa-Silva JH, Lima CR, Silva EJ, Araújo AV, Fraga MC, Ribeiro AR, et al. Acute and subacute toxicity of the Carapa guianensis Aublet (Meliaceae) seed oil. J Ethnopharmacol 2008;116:495-500.

20. Jagetia GC, Baliga MS, Malagi KJ, Kamath MS. The evaluation of the radioprotective effect of Triphala (an ayurvedic rejuvenating drug) in the mice exposed to $\gamma$-radiation. Phytomedicine 2002;9:99108.

21. Bailey JM, Hutsell BA, Newland MC. Dietary nimodipine delays the onset of methylmercury neurotoxicity in mice. Neurotoxicology 2013;2013:108-17.

22. Ohkawa H, Ohishi N, Yagi K. Assay for lipid peroxides in animal tissues thiobarbituric acid reaction. Anal Biochem 1979;95:351-8.

23. Marklund S, Marklund G. Involvement of the superoxide anion radical in the autoxidation of pyrogallol and a convenient assay for superoxide dismutase. Eur J Biochem 1974;47:469-74.

24. Aebi H. Catalase in vitro. In: Methods in Enzymology. Vol 105. USA: Academic Press; 1984. p. 121-6.

25. Rotruck JT, Pope AL, Ganther HE, Swanson AB, Hafeman DG, Hoekstra WG. Selenium: Biochemical role as a component of glutathione peroxidase. Science 1972;179:588-90.

26. Ellman GL, Courtney KD, Andres VJ, Featherstone RM. A new and rapid colorimetric determination of acetylcholinesterase activity. Biochem Pharmacol 1961;7:88-95.

27. Levine RL, Garland D, Oliver CN, Amici A, Climent I, Lenz AG, et al. Determination of carbonyl content in oxidatively modified proteins. Methods Enzymol 1990;186:464-78.

28. Lowry OH, Rosebrough NJ, Farr AL, Randall RJ. Protein measurement with the folin phenol reagent. J Biol Chem 1951;193:265-75.

29. Raouf GA, Qusti SY, Ali AM, Dakhakhni TH. The mechanism of 2, 4-dichlorophenoxyacetic acid neurotoxicity on rat brain tissue by using FTIR spectroscopy. Life Sci J 2012;9:1686-97.

30. Yanpallewar SU, Rai S, Kumar M, Acharya SB. Evaluation of antioxidant and neuroprotective effect of Ocimum sanctum on transient cerebral ischemia and long-term cerebral hypoperfusion. Pharmacol Biochem Behav 2004;79:155-64.

31. Parihar MS, Pandit MK. Free radical induced increase in protein carbonyl is attenuated by low dose of adenosine in hippocampus and mid brain: Implication in neurodegenerative disorders. Gen Physiol
Biophys 2003;22:29-39.

32. Liu R, Liu IY, Bi X, Thompson RF, Doctrow SR, Malfroy B, et al. Reversal of age-related learning deficits and brain oxidative stress in mice with superoxide dismutase/catalase mimetics. Proc Natl Acad Sci 2003;100:8526-31.

33. Domijan AM, Kamilo R, Peraica M. The effect of ochratoxin a on the concentration of protein carbonyls in rats. Arch Ind Hyg Toxicol 2005;56:311-5.

34. Łukaszewicz-Hussain A. Activities of brain antioxidant enzymes, lipid and protein peroxidation. Cent Eur J Med 2011;6:588-94.

35. Tair K, Kharoubi O, Hellal N, Benyettou I, Aoues A. Aluminiuminduced acute neurotoxicity in rats: Treatment with aqueous extract of Arthrophytum (Hammada scoparia). J Acute Dis 2016;5:470-82.

36. Pandya JD, Nukala VN, Sullivan PG. Concentration dependent effect of calcium on brain mitochondrial bioenergetics and oxidative stress parameters. Front Neuroenergetics 2013;5:1-12.

37. Adam-Vizi V, Starkov AA. Calcium and mitochondrial reactive oxygen species generation: How to read the facts. J Alzheimers Dis 2010;20:S413-26.

38. Kumar N, Singh N, Jaggi AS. Anti-stress effects of cilnidipine and nimodipine in immobilization subjected mice. Physiol Behav 2012;105:1148-55.

39. Sharma OP, Dawra RK, Makkar HP. Isolation and partial purification of Lantana (Lantana camara L.) Toxins. Toxicol Lett 1987;37:165-72.

40. Bruey JM, Bruey-Sedano N, Luciano F, Zhai D, Balpai R, Xu C, et al. $\mathrm{Bcl}-2$ and $\mathrm{Bcl}-\mathrm{X} \mathrm{L}$ regulate proinflammatory caspase- 1 activation by interaction with NALP1. Cell 2007;129:45-56.

41. Kim N, Yoo JC, Han JY, Hwang EM, Kim YS, Jeong EY, et al. Human nuclear clusterin mediates apoptosis by interacting with Bcl-XL through C-terminal coiled coil domain. J Cell Physiol 2011;227:1157-67.

42. Bevilacqua AH, Suffredini IB, Romoff P, Lago JH, Bernardi MM. Toxicity of apolar and polar Lantana camara L. crude extracts in mice. Res Vet Sci 2011;90:106-15.

43. Pathan JK, Gautam G, Gupta AK. Evaluation of CNS depressant and muscle relaxant activity of Lantana camara L. stem and flowers. Int J Pharm Biol Sci 2019;9:461-8.

44. Kataki MS, Kumar KT, Rajkumari A. Neuropsychopharmacological profiling of flunarizine: A calcium channel blocker. Int J PharmTech Res 2010;2:1703-13.

45. He P, Wang A, Xia T, Gao LJ, Chen XM. Mechanisms underlying the developmental neurotoxic effect of PBDE-47 and the enhanced toxicity associated with its combination with PCB153 in rats. Neurotoxicology 2009;30:1088-95.

46. Devi MR, Bawari M, Paul SB, Sharma GD. Characterization of the toxic effects and ultrastructural approach. Asian J Pharm Clin Res 2012;5 Suppl 3:143-6.

\footnotetext{
How to cite this article:

Singha HA, Sengupta M, Bawari M. Biochemical and ultrastructural alterations in the brain of mice induced by aqueous leaf extract of a medicinal plant, Lantana camara $\mathrm{L}$. and its amelioration by nimodipine and flunarizine. J App Biol Biotech. 2021;9(3):66-74.

DOI: $10.7324 / J A B B .2021 .9309$
} 


\section{SUPPLEMENTARY MATERIAL}

Power analysis of the study

To avoid Type-II error, power analysis is conducted for independent samples.

\begin{tabular}{llll} 
& & Cerebrum & Cerebebellum \\
Glutathione peroxidase & 0.999 & 0.979 & 0.999 \\
Superoxide dismutase & 1.000 & 1.000 \\
Catalase & 1.000 & 1.000 \\
Lipid peroxidase & 1.000 & 0.918 \\
Acetylcholinesterase & 0.995 & 0.965 \\
Protein carbonyl content & 0.989 & \\
\hline
\end{tabular}

Total number of samples per experiment $=30$

In the above table, it is clearly indicated that the observed power are more than $80 \%$ which inclined that the null hypothesis are correctly rejected. Therefore, the sample size is suitable to detect the effect of a given test at the desired level of significance. 